УДК 633:631.53.027:631.878
(C) 2017

Маренич М. М., кандидат сільськогосподарських наук, доцент

Полтавська державна аграрна академія

\title{
ПЕРЕДПОСІВНА ОБРОБКА НАСІННЯ ЯК ЕЛЕМЕНТ УПРАВЛІННЯ ПРОДУКТИВНИМ ПОТЕНЦААЛМ ПШЕНИЦІ ОЗИМОЇ
}

\author{
Рецензент - доктор сільськогосподарських наук, професор М. Я. Шевніков
}

\begin{abstract}
Наведені результати досліджень використання протруйників та гуматів для передпосівної обробки насіння. Встановлено, шео додавання гуматів у суміші з протруйниками закономірно підвищувало показники польової схожості та кількості вузлових коренів порівняно з контролем. Середньорічні показники свідчать про закономірний вплив застосування стимуляторів на скорочення періоду «сівба-сходи», проте за несприятливих умов проростання застосування стимуляторів може відігравати дуже важливу роль для отримання дружних сходів.

У випадку застосування гуматів польова схожість насіння зросла на 11-13\%. За несприятливих умов, щуо склалися на період проростання дія факторів посилювалася $i$ збільшувався вплив таких взаємодій як «попередники-сорт» та «сорт-варіант обробки насіння».

Утворення вузлових коренів також істотно залежало від варіанту обробки насіння. Найкращчим показником характеризувався варіант досліду, де використовувався "1R Seed treatment», щчо в подальшому значною мірою вплинуло на формування врожайності.

У всіх проведених дослідах відзначали позитивний вплив застосування для обробки насіння стимуляторів «Гуміфілд» та «1R Seed treatment» як у сумішах 3 протруйниками, так $i$ у варіантах, де вони використовувалися окремо.
\end{abstract}

Ключові слова: пшениия озима, енергія проростання, схожість, протруйник, стимулятори.

Постановка проблеми. Сучасна технологія вирощування пшениці озимої передбачає застосування широкого комплексу агротехнічних засобів, ключовим 3 яких є передпосівна обробка насіння. Саме цей прийом дає змогу в значній мірі уникнути впливу негативних факторів вирощування на ріст і розвиток рослин на початкових стадіях, тому сучасні технології вирощування передбачають його як обов'язковий.

У науковій і науково-виробничій літературі точиться досить гостра дискусія про вплив протруйників та їх композицій зі стимуляторами росту на такі параметри як тривалість періоду «сівба-сходи», польову схожість насіння, розвиток кореневої системи та інші показники. Значна частина дослідників доводить здебільшого нега- тивний вплив протруйників на показники енергії проростання та польової схожості та рекомендує використовувати стимулятори росту. 3 іншого боку доводиться тезис про відсутність шкідливого впливу хімічних препаратів на ці показники.

Аналіз останніх досліджень та публікацій, у яких започатковано розв'язання проблеми. Наукові дослідження і виробничий досвід свідчать про істотний позитивний ефект від застосування передпосівної обробки зерна, проте застосування лише захисних речовин для цього прийому може значно знизити енергію проростання й польову схожість насіння. Попри те, що оброблене протруйниками насіння має певні переваги перед необробленим у кращій стійкості до ураження шкідливими організмами, в зоні нестійкого чи недостатнього зволоження цей фактор може відіграти негативну роль і матиме більшу залежність від погодних умов. Окрім зазначеного ефективність дії протруйників у значній мірі може залежати від фітосанітарного стану поля та якості насіннєвого матеріалу, фону удобрення тощо [7]. Це, в свою чергу, може призвести до недобору врожаю.

Для уникнення такої ситуації і виробничники, i вчені пробують застосування комбінованих препаратів захисту зі стимуляторами росту органічного походження. Вони значно пом'якшують фітотоксичність препаратів, стимулюють процеси проростання й подальшого росту та значною мірою збільшують імунний потенціал рослин [1, $8,6]$.

В останні роки в якості стимуляторів для передпосівної обробки насіння використовуються гумати. Переважна більшість дослідників однозначно говорять про позитивні результати використання препаратів цієї групи як для обробки насіння, так і для позакореневих підживлень чи внесення в грунт. Проте й тут існують певні тонкощі для застосування [3].

За деякими даними збільшення врожайності зернових культур від обробки насіння гуміновими речовинами може сягати $1,2-4,5$ ц/га. Проте від себе відразу відзначимо, що така прибавка навіть за врожайності 40 ц/га становить лише 3- 


\section{СІЛЬСЬКЕ ГОСПОДАРСТВО. РОСЛИННИЦТВО}

11,3 \%, тобто іiі мінімальний рівень знаходиться в межах помилки досліду. Сучасні препарати дають змогу отримувати набагато солідніші прибавки. Наприклад, застосування гуміфілду в разі обробки насіння і позакореневого внесення сприяло підвищенню врожайності пшениці на 410 ц/га [2].

У наших власних дослідженнях було доведено, що гумати $є$ досить ефективним способом, який забезпечує підвищення енергії проростання, схожості, маси проростка та інших показників як у лабораторних умовах, так і в полі [5, 4].

Метою досліджень було подальше визначення впливу передпосівної обробки насіння хімічними препаратами, гуматами та їх комбінацій на тривалість періоду «сівба-сходи», польову схожість, кількість вузлових коренів для встановлення оптимального варіанту передпосівної обробки. Для цього були сформульовані наступні завдання:

в першому багатофакторному досліді визначали вплив протруйника «Максим Стар 025 FS» у рекомендованих дозах, гуматів та їх сумішей для обробки насіння пшениці озимої;

у другому польовому багатофакторному досліді визначали вплив цих же гуматів та їх сумішей $з$ комплексною обробкою насіння фунгіцидами та інсектицидами.

Матеріал i методика проведення досліджень. Матеріалом для експерименту стали зразки насіння сортів пшениці озимої Левада, Смуглянка, Славна. Насіння оброблялось рекомендованими дозами протруйників та стимуляторів росту гумінового походження 3 розрахунку 8 л розчину на тону насіння.

Повторність польового досліду - триразова. Біометричні показники визначали на 15-й день після отримання сходів. Для обробки результатів використовувалися метод багатофакторного дисперсійного аналізу, статистичну обробку результатів здійснювали за допомогою програми STATISTICA 10.0 .

Результати досліджень. Показники, які досліджувалися в даному експерименті, значною мірою залежать від умов навколишнього середовища, які в роки досліджень характеризувалися як контрастні i, навіть, як екстремальні для проростання насіння. Так, у 2014 році умови проростання були практично оптимальними і середня тривалість появи сходів становила в середньому сім діб, однак осінь 2015 року характеризувалася тривалим посушливим періодом. Відсутність дощів у другій половині літа також не сприяла накопиченню вологи в грунті. Як наслідок, три- валість періоду «сівба-сходи» була довшою майже в 6-7 разів і становила для першого досліду 47, а для другого - 40 діб. У виробничих посівах сходи були отримані ще пізніше - появу сходів у деяких господарствах відзначали в грудні.

Подібними умовами характеризувався і 2016 рік, однак в першій половині літа випала значна кількість дощів, тому умови проростання були дещо м'якшими від попередніх і завдяки цьому для отримання сходів рослини потребували 1419 діб. Проте в деяких господарствах сходи у виробничих посівах були отримані значно пізніше і лише сприятливі умови зими дали аграріям підстави для оптимізму. Внаслідок такого стану речей показники досліду значно відрізнялися від звичних. Проте, можливо, саме такі умови дали змогу встановити можливу дію і взаємодію факторів у досліді.

За усередненими даними використання для передпосівної обробки насіння препарату «Максим Стар 025 FS» не призводило до затримки сходів, але помітно впливало на польову схожість насіння (табл. 1). Різниця між контрольним варіантом та варіантом, де застосовувався лише фунгіцид, становила лише 2-4 \%, що в цілому може знаходитися в межах помилки досліду, проте була закономірною.

Передпосівна обробка насіння виявилася найефективнішою в разі застосування препарату «1R Seed treatment», хоча й обробка лігногуматом натрію, «Радостимом» та «Гуміфілдом» також сприяла підвищенню польової схожості насіння на 6-11\% та збільшенню кількості вузлових коренів у рослин майже на два корінця. Додавання гуматів у суміші 3 фунгіцидом також закономірно підвищувало показники польової схожості та кількості вузлових коренів порівняно $з$ контролем. Таким чином, в усі роки досліджень спостерігалась позитивна дія стимуляторів росту в рекомендованих дозах на показники сходів і розвитку рослин у перші етапи осіннього розвитку.

У другому досліді попередні закономірності фактично підтвердилися. За контроль було взято варіант зі стандартним захистом насіння в композиції фунгіцида 3 інсектицидом - обробка «Венцедором» та «Командором екстра» в нормах 1,2 і 0,6 л/т відповідно.

Середньорічні показники, наведені в таблиці 2 свідчать про закономірний вплив застосування стимуляторів на скорочення періоду «сівбасходи», однак за роками вплив факторів, що досліджувалися в досліді мав свої особливості. 


\section{1. Вплив передпосівної обробки насіння на показники схожості (2014-2016 рр.)}

\begin{tabular}{|c|c|c|c|}
\hline Варіант & $\begin{array}{c}\text { Тривалість } \\
\text { періоду } \\
\text { «сівба-сходи» }\end{array}$ & $\begin{array}{c}\text { Польова } \\
\text { схожість, } \\
\text { \% }\end{array}$ & $\begin{array}{c}\text { Утворення } \\
\text { вузлових } \\
\text { коренів, шт }\end{array}$ \\
\hline \multicolumn{4}{|c|}{ Левада } \\
\hline Контроль (без обробки) & 24 & 75 & 3,11 \\
\hline «Максим Стар 025 FS», 1,5 л/т & 24 & 71 & 3,11 \\
\hline «Радостим», 0,25 л/т & 24 & 79 & 3,11 \\
\hline Лігногумат натрію, 0,5 л/т & 23 & 81 & 3,67 \\
\hline «Гуміфілд», 0,5 л/т & 23 & 83 & 3,89 \\
\hline $1 \mathrm{R}, 1,0$ л/т & 22 & 86 & 5,11 \\
\hline «Максим Стар 025 FS», 1,5 л/т + «Гуміфілд», 0,5 л/т & 24 & 78 & 3,78 \\
\hline «Максим Стар 025 FS», 1,5 л/т + 1R 1,0 л/т & 23 & 81 & 5,00 \\
\hline \multicolumn{4}{|c|}{ Славна } \\
\hline Контроль (без обробки) & 24 & 70 & 2,78 \\
\hline «Максим Стар 025 FS», 1,5 л/т & 24 & 67 & 3,11 \\
\hline «Радостим», 0,25 л/т & 23 & 74 & 3,67 \\
\hline Лігногумат натрію, 0,5 л/т & 23 & 76 & 3,44 \\
\hline «Гуміфілд», 0,5 л/т & 23 & 79 & 3,33 \\
\hline $1 \mathrm{R}, 1,0$ л/т & 22 & 85 & 4,56 \\
\hline «Максим Стар 025 FS», 1,5 л/т + «Гуміфілд», 0,5 л/т & 23 & 77 & 3,44 \\
\hline «Максим Стар 025 FS», 1,5 л/т + 1R, 1,0 л/т & 23 & 81 & 4,22 \\
\hline \multicolumn{4}{|c|}{ Смуглянка } \\
\hline Контроль (без обробки) & 23 & 72 & 2,67 \\
\hline «Максим Стар 025 FS», 1,5 л/т & 23 & 68 & 3,22 \\
\hline «Радостим», 0,25 л/т & 23 & 76 & 3,33 \\
\hline Лігногумат натрію, 0,5 л/т & 23 & 77 & 4,11 \\
\hline «Гуміфілд», 0,5 л/т & 23 & 79 & 4,11 \\
\hline $1 \mathrm{R}, 1,0$ л/т & 22 & 82 & 5,00 \\
\hline «Максим Стар 025 FS», 1,5 л/т + «Гуміфілд», 0,5 л/т & 23 & 75 & 3,67 \\
\hline «Максим Стар 025 FS», 1,5 л/т + 1R, 1,0 л/т & 23 & 78 & 4,67 \\
\hline$H I P_{05} 2014$ & 1,3 & 5,39 & 1,41 \\
\hline$H I P_{05} 2015$ & 1,1 & 12,75 & 1,78 \\
\hline$H I P_{05} 2016$ & 1,1 & 9,22 & 1,64 \\
\hline
\end{tabular}

Зокрема у 2014 році, коли умови для сходів були оптимальними за допомогою багатофакторного дисперсійного аналізу було встановлено, що на даний показник впливає лише варіант обробки та його взаємодія з сортовими властивостями. Однак у 2015 та 2016 роках істотним був вплив попередників, сортових властивостей, варіанту обробки та їх взаємодії. 3 цього можна зробити висновок, що за несприятливих умов застосування стимуляторів може відігравати дуже важливу роль для отримання дружних сходів.

Подібним виявився також вплив обробки насіння й на показник польової схожості. Середні дані за цим показником переконливо демонструють ефективність застосування для обробки гуматів та використання їх у композиціях 3 протруйниками. Для прикладу у сорту Смуглянка польова схожість насіння зросла на $11,3 \%$, а в сорту Славна - на $12 \%$ після використання як попередника сої. У варіантах, де попередником була картопля польова схожість насіння виявилася кращою, а різниця між варіантами і контролем знаходилася в межах 11-13\%. Показник польової схожості також реагував на умови років подібним до попереднього показника чином, тобто за несприятливих умов дія факторів поси- 
лювалася і збільшувався вплив таких взаємодій як «попередники-сорт» та «сорт-варіант обробки насіння».

У всіх без винятку проведених дослідах відзначали позитивний вплив застосування для обробки насіння стимуляторів «Гуміфілд» та «1R Seed treatment» як у сумішах 3 протруйниками, так і у варіантах, де вони використовувалися окремо.

Утворення вузлових коренів також істотно залежало від варіанту обробки насіння. Найкращим показником характеризувався варіант до- сліду, де використовувався «1R Seed treatment»різниця між цим варіантом і контролем складала в середньому за трирічними даними 1-2 корінця, що в подальшому значною мірою вплинуло на формування врожайності.

Аналізуючи результати статистичного аналізу, можна помітити закономірність: на формування впливу показників, які описуються в даній статті найбільший вплив у переважній більшості має підбір попередника, потім сортові властивості та їх взаємодія.

2. Вплив попередників та передпосівної обробки насіння на показники схожості (2014-2016 рр.)

\begin{tabular}{|c|c|c|c|c|}
\hline 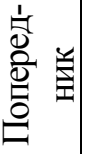 & Варіант & $\begin{array}{c}\text { Тривалість } \\
\text { періоду } \\
\text { «сівба-сходи» }\end{array}$ & $\begin{array}{c}\text { Польова } \\
\text { схожість, } \\
\text { \% }\end{array}$ & $\begin{array}{c}\text { Утворення } \\
\text { вузлових } \\
\text { коренів, шт. }\end{array}$ \\
\hline \multirow{12}{*}{ 范 } & \multicolumn{4}{|c|}{ Смуглянка } \\
\hline & «Венцедор» 1,2 л/т + «Командор екстра» 0,6 л/т & 23 & 76,0 & 2,5 \\
\hline & «Гуміфілд» 0,5 л/т & 22 & 81,3 & 2,7 \\
\hline & 1R 1 л/т & 20 & 87,3 & 3,5 \\
\hline & $\begin{array}{l}\text { «Венцедор» 1,2 л/т + «Командор екстра» } 0,6 \text { л/т + } \\
0,5 \text { л/т «Гуміфілд» }\end{array}$ & 22 & 79,7 & 2,7 \\
\hline & $\begin{array}{l}\text { «Венцедор» 1,2 л/т + «Командор екстра» } 0,6 \text { л/т + } \\
\text { 1R } 1 \text { л/T }\end{array}$ & 21 & 83,3 & 2,9 \\
\hline & \multicolumn{4}{|c|}{ Славна } \\
\hline & «Венцедор» 1,2 л/т + «Командор екстра» 0,6 л/т & 21 & 71 & 2,2 \\
\hline & «Гуміфілд» 0,5 л/т & 21 & 76 & 2,5 \\
\hline & $1 \mathrm{R} 1$ л/т & 20 & 83 & 3,3 \\
\hline & $\begin{array}{l}\text { «Венцедор» 1,2 л/т + «Командор екстра» 0,6 л/т + } \\
\text { 0,5 л/т «Гуміфілд» }\end{array}$ & 22 & 73 & 2,3 \\
\hline & $\begin{array}{l}\text { «Венцедор» 1,2 л/т + «Командор екстра» } 0,6 \text { л/т + } \\
\text { 1R } 1 \text { л/т }\end{array}$ & 20 & 77 & 3,0 \\
\hline \multirow{12}{*}{ 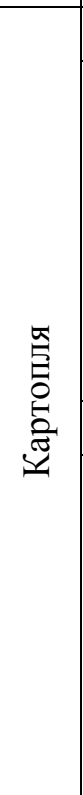 } & \multicolumn{4}{|c|}{ Смуглянка } \\
\hline & «Венцедор» 1,2 л/т + «Командор екстра» 0,6 л/т & 22 & 80 & 2,8 \\
\hline & «Гуміфілд» 0,5 л/т & 21 & 83 & 3,1 \\
\hline & $1 \mathrm{R} 1$ л/т & 20 & 91 & 3,9 \\
\hline & $\begin{array}{l}\text { «Венцедор» 1,2 л/т + «Командор екстра» 0,6 л/т + } \\
0,5 \text { л/т «Гуміфілд» }\end{array}$ & 21 & 84 & 3,1 \\
\hline & $\begin{array}{l}\text { «Венцедор» 1,2 л/т + «Командор екстра» } 0,6 \text { л/т + } \\
\text { 1R } 1 \text { л/т }\end{array}$ & 21 & 87 & 3,7 \\
\hline & \multicolumn{4}{|c|}{ Славна } \\
\hline & «Венцедор» 1,2 л/т + «Командор екстра» 0,6 л/т & 22 & 76 & 2,8 \\
\hline & «Гуміфілд» 0,5 л/т & 20 & 81 & 3,3 \\
\hline & 1R 1 л/т & 20 & 89 & 4,0 \\
\hline & $\begin{array}{l}\text { «Венцедор» 1,2 л/т + «Командор екстра» 0,6 л/т + } \\
\text { 0,5 л/т «Гуміфілд» }\end{array}$ & 21 & 80 & 3,1 \\
\hline & $\begin{array}{l}\text { «Венцедор» 1,2 л/т + «Командор екстра» 0,6 л/т + } \\
\text { 1R } 1 \text { л/т }\end{array}$ & 20 & 84 & 4,1 \\
\hline \multicolumn{2}{|c|}{$H I P_{05}$} & & & \\
\hline
\end{tabular}


Проте застосування для обробки насіння гуматів має також істотне значення, при чому ї дія підтверджується на досить високому рівні значущості-0,01.

За результатами проведених досліджень можна сказати, що передпосівна обробка насіння протруйниками має ризик зниження польової схожості насіння, проте в подальшому цей прийом компенсується кращим захистом рослин від шкідливих організмів i, як наслідок, збільшенням врожайності. Застосування ж для передпосівної обробки стимуляторів може нівелювати таку негативну дію та зробити розвиток рослин більш регульованим, тобто дасть змогу краще управляти агроценозами, починаючи 3 перших етапів розвитку рослин.

Результати досліджень демонструють ефективність застосування для обробки гуматів та використання їх у композиціях з протруйниками польова схожість зростала на 11-13\% порівняно 3 контрольним варіантом.

Утворення вузлових коренів істотно залежало від варіанту обробки насіння. Найкращим показником характеризувався варіант досліду, де ви-

\section{БІБЛІОГРАФІЯ}

1. Герасименко С. М. Регулятори росту долають фітотоксичний ефект / С. М. Герасименко // Зерно. - 2006. - №5. - С. 63.

2. Козаренко Д. О. Застосування гуматів - перспективний метод зменшення хімічного навантаження на агроценози / Д.О. Козаренко [Електронний ресурс] // Карантин і захист рослин. 2013. - №8. - С. 14-16. - Режим доступу : http://nbuv.gov.ua/UJRN/Kizr_2013_8_8.

3. Крамарёв С. М. Перспективы комплексного применения гуминовых препаратов, микроэлементов в хелатной форме и препарата Марс для предпосевной инкрустации / С. М. Крамарёв // Radostim 2007. Гуминовые кислоты и фитогормоны в растениеводстве (Киев, Украина, 12-16 июня 2007). Сборник материалов Международной конференции, в рамках выставки Агро 2007. - K., 2007. - C. 31-32.

4. Маренич М. М. Вплив допосівної обробки насіння біологічно активними речовинами на ріст і розвиток рослин пшениці озимої на початкових стадіях / М. М. Маренич, С. О. Юрченко // Вісник Полтавської державної аграрної академії. користовувався «1R Seed treatment»- різниця між цим варіантом і контролем становила в середньому за трирічними даними 1-2 корінця, що в подальшому значною мірою вплинуло на формування врожайності.

Висновок. Використання для передпосівної обробки насіння препарату «Максим Стар 025 FS» не призводило до затримки сходів, але помітно впливало на польову схожість насіння.

Додавання гуматів у суміші з фунгіцидом закономірно підвищувало показники польової схожості та кількості вузлових коренів порівняно 3 контролем. Таким чином, в усі роки досліджень спостерігалась позитивна дія стимуляторів росту в рекомендованих дозах на показники сходів і розвитку рослин у перші етапи осіннього розвитку.

За несприятливих умов застосування стимуляторів може відігравати дуже важливу роль для отримання дружних сходів.

Застосування для обробки насіння гуматів має також істотне значення, при чому їх дія підтверджується на досить високому рівні значущості 0,01 .

- 2017. - №1-2. - C. 38-42.

5. Маренич М. М. Посівні властивості насіння сільськогосподарських культур залежно від застосування стимуляторів росту / М. М. Маренич, С. О. Юрченко // Вісник Полтавської державної аграрної академії. - 2016. - №1-2. - С. 18-21.

6. Підвищення регуляторами росту імунітету рослин до патогенних грибів, шкідників і нематод / [Циганкова В. А., Андрусевич Я. В., Бабаянц О. В., Пономаренко С. П., Медков А. І., Галкін А. П.] // Физиология и биохимия культурных растений. - 2013. - Т. 45, №2 - С. 138-147.

7. Протруєння насіння: переваги і підводні камені / [Авраменко С., Попов С., Циганко В., Курилов О.] [Електронний ресурс] // Пропозиція. - Режим доступу до журн. : http://propozitsiya.com/ua/protruiennya-nasinnyaperevagi-i-pidvodni-kameni.

8. Скачок Л. М. Ефективність біологічних добрив і стимуляторів росту на польових культуpax / Л. М. Скачок, Л. В. Потапенко, Т. М. Ярош // Сільськогосподарська мікробіологія. - Чернігів, 2008. - Вип. 7. - С. 122-130. 